\title{
Effects of Harvest Date on Long-term Storability of On-tree Alcohol-treated 'Hiratanenashi' Persimmons Packed in Plastic Film
}

\author{
Taira Satoshi* ${ }^{\S}$, Imai Eriko* and GoheI Masato* \\ * Faculty of Agriculture, Yamagata University, 1-23 Wakaba-machi, Tsuruoka, Yamagata 997-8555
}

\begin{abstract}
We investigated the effects of harvest date on the storability in cold storage $\left(1{ }^{\circ} \mathrm{C}\right.$ and $5{ }^{\circ} \mathrm{C}$ ), of ontree alcohol-treated 'Hiratanenashi' persimmons packed individually in plastic film. The persimmons, treated with ethanol on the tree to remove astringency on Oct.3 (108 days after full bloom), were harvested on Nov.2 (the color score near the fruit apex was about 5), Nov.10 (the color score near the fruit apex was about 6 and the fruit surface was fully colored), and Nov.16 (the color score near the fruit apex was about 7 ). These persimmons were packed individually directly after harvesting in plastic film and were stored at $1{ }^{\circ} \mathrm{C}$ and $5{ }^{\circ} \mathrm{C}$. The fruit samples from each harvesting date stored at $1{ }^{\circ} \mathrm{C}$ had better storability than the fruit samples stored at $5{ }^{\circ} \mathrm{C}$. At either storage temperature, the fruit samples harvested on Nov. 2 had the highest storability. The storability of the fruit samples harvested on Nov. 2 judged by the rate of fruit softening was at least three months under cold storage at $1{ }^{\circ} \mathrm{C}$. Peel color index, flesh firmness, and soluble solid concentration of the fruit samples from each harvesting date at both storage temperatures changed very little during storage. The scores for eating quality of all fruit samples decreased slightly as the duration of cold storage was prolonged. Fluctuations in the score of the fruit samples stored at $5{ }^{\circ} \mathrm{C}$ were larger than that of the fruit samples stored at $1{ }^{\circ} \mathrm{C}$. The eating quality of the fruit samples harvested on Nov. 2 was fairly good during the three month storage period.
\end{abstract}

(Received Sep. 5, 2007 ; Accepted Jan. 7, 2008)

Key words : astringency removal, film packaging, flesh softening, storability, persimmon

脱渋, フィルム包装, 果肉軟化, 貯蔵性, カキ

It is generally accepted that the storability of slightly immature fruit is higher than that of fully ripened or over-ripened fruit in most species. This fact is often demonstrated with experimental or commercial observations of apples ${ }^{1)}$. Similar observations have been reported for non-astringent persimmons $^{2,3)}$. In contrast, astringent persimmons, after the removal of astringency, have a different trend for their storability. The storage life of astringent persimmons after post-harvest treatment to remove astringency may increase when the fruit samples are harvested fully ripened or at the stage of full color development on the fruit surface ${ }^{4), 5}$.

We reported previously that 'Hiratanenashi' persimmon, a leading astringent cultivar in Japan, has fairly good storability in cold storage when packed individually in plastic film ${ }^{6}$. On-tree alcohol treatment of 'Hiratanenashi' fruit to remove astringency also resulted in good storage quality in cold storage for about three months ${ }^{7)}$. We discussed in the above report that the storability of on-tree alcohol-treated persimmons during cold storage might be affected by the harvest maturity of the fruit. It may be very interesting to know if on-tree alcohol-treated persimmons show the same characteristics as non-astringent or astringent persimmons.

In this report, we examined the effects of harvest date on the storability of on-tree alcohol-treated 'Hiratanenashi' persimmons to answer this question.

\section{Materials and Methods}

\section{Fruit material}

The 'Hiratanenashi' persimmon fruit were harvested from adult trees in the experimental orchard (Sakata City) of the Research Laboratory for Sources of Agricultural Products in Shonai District, Yamagata Prefecture, Japan.

$\S$ Corresponding author, E-mail : staira@tds1.tr.yamagata-u.ac.jp 
The on-tree alcohol-treated persimmons (the method of on-tree treatment for removing astringency will be described later) were picked on three different dates, Nov.2 (the color score near the fruit apex was about ${ }^{5)}$ Nov. 10 (the color score near the fruit apex was about 6 and the fruit surface was fully colored), and Nov. 16 (the color score near the fruit apex was about ${ }^{7)}$. Cracked and damaged fruits were removed in advance, and fruits of $\mathrm{L}(190 \sim 220 \mathrm{~g})$ or $2 \mathrm{~L}(221 \sim 250 \mathrm{~g})$ class were selected randomly for the following storage experiments.

\section{Methods for removing astringency, packaging, and storage}

On-tree treatment for removing astringency was carried out as described previously ${ }^{8)}$. Each persimmon was individually covered on the tree with a polyethylene bag containing a solid alcohol 108 days after full bloom. The bottom of the bag was cut with scissors 48 hours after the start of bagging.

The packaging of the fruit after harvest was conducted by the same method as reported by TAIRA and ISOBE ${ }^{6)}$. The fruit was individually packed in a plastic film (a complex film of polyethylene and polypropylene, $0.055 \mathrm{~mm}$ in thickness, Okura Kogyo Co.) with an ethylene absorber ('Ace Pack', $2.0 \mathrm{~g}$, Dai-ichi Nozai Co.).

Soon after the fruits were packed, they were divided into 2 groups for each harvesting date and were placed in refrigerators regulated at $1+1{ }^{\circ} \mathrm{C}$ and $5+1{ }^{\circ} \mathrm{C}$. The numbers of fruits used were 100 and 160 for storage at $1{ }^{\circ} \mathrm{C}$ and $5{ }^{\circ} \mathrm{C}$, respectively.

\section{3 . Evaluations of fruit quality}

The rate of fruit softening was estimated as reported previously ${ }^{6), 7)}$ using 50 fruits from $1{ }^{\circ} \mathrm{C}$ storage and 100 fruits from $5{ }^{\circ} \mathrm{C}$ storage. A softened fruit sample, which has low marketability, was defined as a fruit with softened flesh that can be crushed easily by pushing with a finger or a fruit with partially water-soaked flesh.

Changes in peel color index, flesh firmness, and soluble solid concentration of the fruit flesh were determined periodically using 5 or 6 fruits $^{6), 7)}$. Peel color near the fruit apex was measured with the color chart for 'Hiratanenashi' persimmon made by the Fruit Research Institute of Japan. Flesh firmness was determined with a Fruit Firmness Meter (Fujiwara Manufacturing Co., $5 \mathrm{~kg}$, equipped with a conical plunger). The soluble solid concentration of the fruit juice was measured with a hand refractometer (ATAGO, ATC-1).

The eating quality of the fruit was judged by 6 panelists. The panelists, 4 females and 2 males, were laboratory students without training. The scores for the eating quality of persimmons were 5 , very good ; 4 , good ; 3 , moderate ; 2 , edible but not good; 1 , bad. Each panelist ate a sample of the flesh and gave it a score from the five ratings above to evaluate the total taste of the persimmon sample.

\section{Results and Discussion}

\section{Fruit softening during storage}

Changes in the proportion of softened fruits during storage are shown in Fig. 1.

Signs of softening started to appear in persimmons harvested on Nov. 10 and Nov. 16, and those harvested on Nov. 2 after 60 days and 100 days of storage at $1{ }^{\circ} \mathrm{C}$, respectively. Half of the
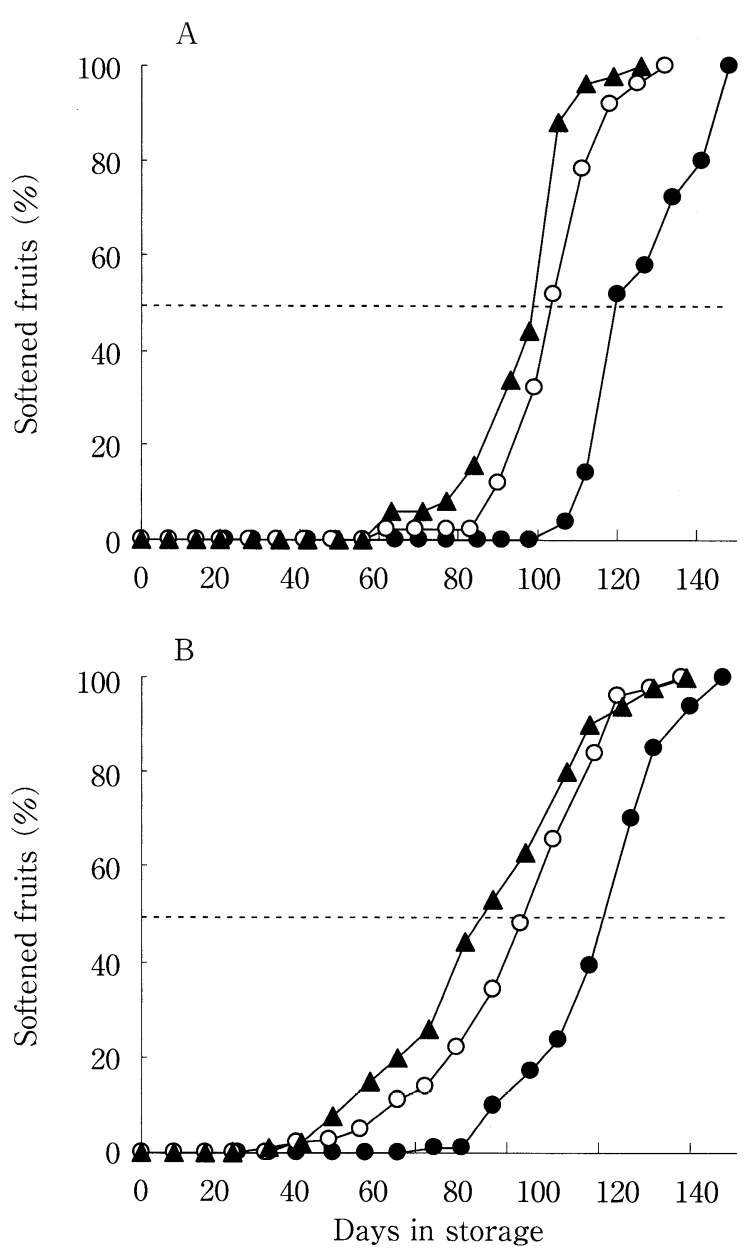

Fig. 1 Effects of harvest dates (O, Nov. 2 ; $\bigcirc$, Nov. 10 ; Nov.16) on fruit softening in Hiratanenashi persimmons packed in plastic film stored at $1{ }^{\circ} \mathrm{C}$ (A) and $5{ }^{\circ} \mathrm{C}$ (B) 
fruits harvested on Nov.10 and Nov.16, and those harvested on Nov. 2 had softened about 100 days and 120 days from the start of storage, respectively. All of the persimmons harvested on Nov. 10 and Nov. 16, and those harvested on Nov. 2 had softened sufficiently to lose their marketability after about 120 days and 150 days in storage, respectively (Fig. 1-A).

The softening of persimmons advanced more rapidly in storage at $5{ }^{\circ} \mathrm{C}$ than in storage at $1{ }^{\circ} \mathrm{C}$. Signs of softening started to appear after 30 days and 70 days in persimmons harvested on Nov. 10 and Nov. 16, and those harvested on Nov. 2, respectively. Half of the fruits harvested on Nov. 10 and Nov.16, and those harvested on Nov. 2 had softened after about 80 days and 100 days after the start of storage, respectively. All of the persimmons harvested on Nov. 10 and Nov. 16, and those harvested on Nov. 2 had softened after about 100 days and 130 days in storage, respectively (Fig. 1-B).

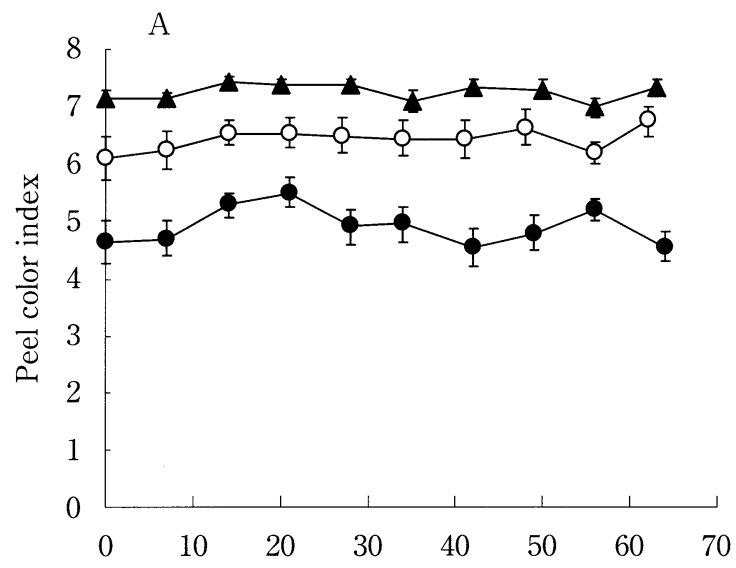

B

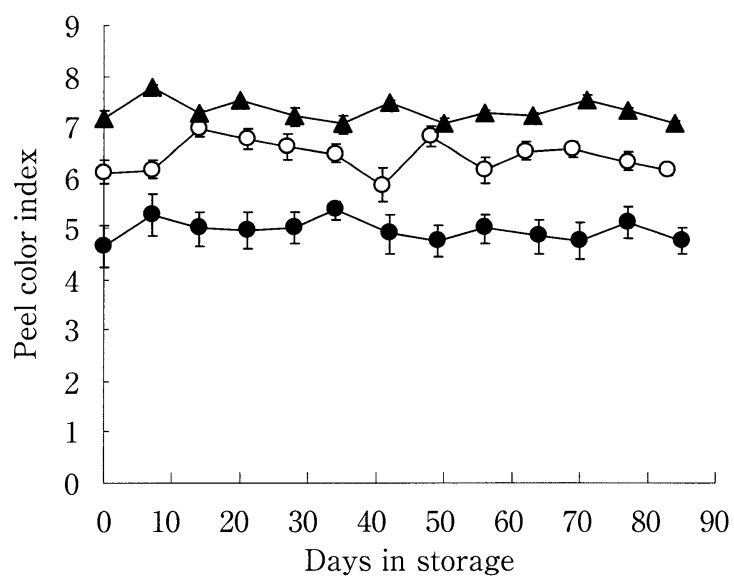

Fig. 2 Effects of harvest dates

Nov. $2 ;$, Nov. $10 ;$ Nov. 16) on peel color change in Hiratanenashi persimmons packed in plastic film stored at $1{ }^{\circ} \mathrm{C}$ (A) and $5{ }^{\circ} \mathrm{C}(\mathrm{B})$
These results clearly show that the storability of on-tree alcohol-treated persimmons is better in fruits harvested a little earlier than full coloring of the fruit surface than in those harvested at the fully ripe or over-ripe stages. On-tree alcohol-treated persimmons harvested a week before full coloring did not soften during about 100 days in storage at $1{ }^{\circ} \mathrm{C}$ and about 70 days in storage at $5{ }^{\circ} \mathrm{C}$.

\section{Changes in fruit quality}

Figures 2,3 , and 4 show the changes in peel color index, flesh firmness, and soluble solid concentration of fruit flesh, respectively.

Although the peel color indexes at harvesting time were different among the fruits harvested on different dates, these indexes changed very little during storage for about 60 days at $1{ }^{\circ} \mathrm{C}$ and for about 85 days at $5{ }^{\circ} \mathrm{C}$ (Fig. 2). Flesh firmness also changed little throughout the storage period at both temperatures for any fruit harvested on different dates (Fig. 3). The soluble solid concentration of the
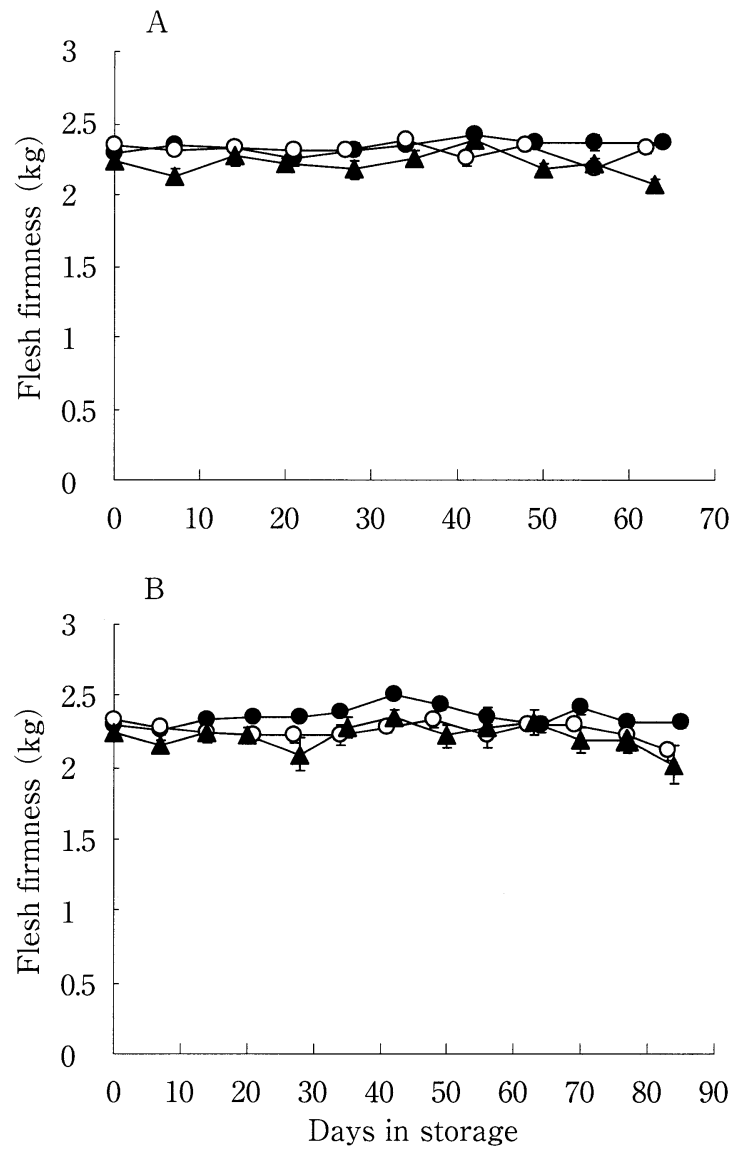

Fig. 3 Effects of harvest dates (O. Nov. 2 ; O, Nov. 10 ; Nov. 16) on changes in flesh firmness in Hiratanenashi persimmons packed in plastic film stored at $1{ }^{\circ} \mathrm{C}$ (A) and $5{ }^{\circ} \mathrm{C}(\mathrm{B})$

Bars represent SE $(n=5)$. 

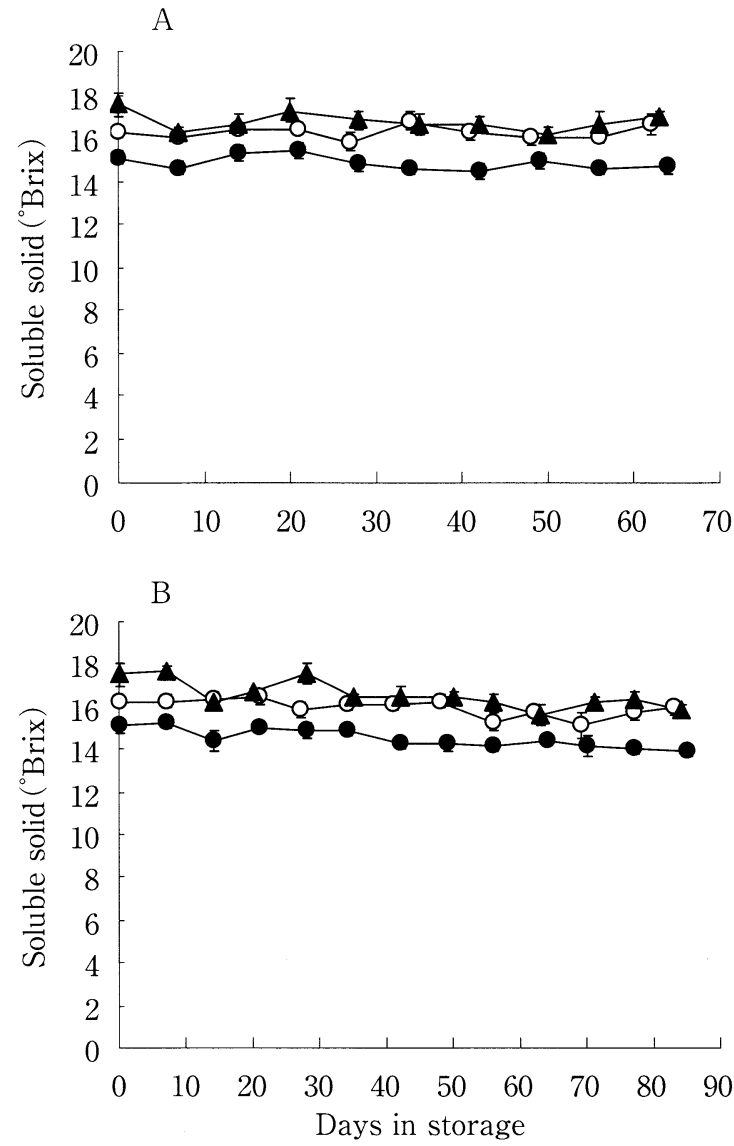

Fig. 4 Effects of harvest dates

Nov. 2 ; , Nov. $10 ;$ Nov. 16) on changes in soluble solid concentration in Hiratanenashi persimmons packed in plastic film stored at $1{ }^{\circ} \mathrm{C}$ (A) and $5{ }^{\circ} \mathrm{C}(\mathrm{B})$.

Bars represent SE $(n=5)$.

flesh of fruit harvested on different dates changed only slightly and decreased a little in storage at $1{ }^{\circ} \mathrm{C}$ and $5{ }^{\circ} \mathrm{C}$, respectively (Fig. 4 ). The concentration of soluble solids in the fruit harvested on Nov.2 was more than $14{ }^{\circ}$ Brix. That was sufficiently high to provide good fruit quality, but was lower than those of the fruits harvested on Nov. 10 and Nov. 16 .

Although the fruit appearance remained almost the same during storage at $1{ }^{\circ} \mathrm{C}$, the appearance of fruits stored at $5{ }^{\circ} \mathrm{C}$ gradually deteriorated as the storage period prolonged, resulting in fine cracks in the peel being observed after 40 days of storage.

The scores for eating quality of persimmons decreased gradually with fluctuations as the storage period extended (Fig. 5). The range of the fluctuations was larger in persimmons stored at $5{ }^{\circ} \mathrm{C}$ than in those stored at $1{ }^{\circ} \mathrm{C}$. Although fluctuations in the eating quality scores of fruits harvested on different dates were observed, the
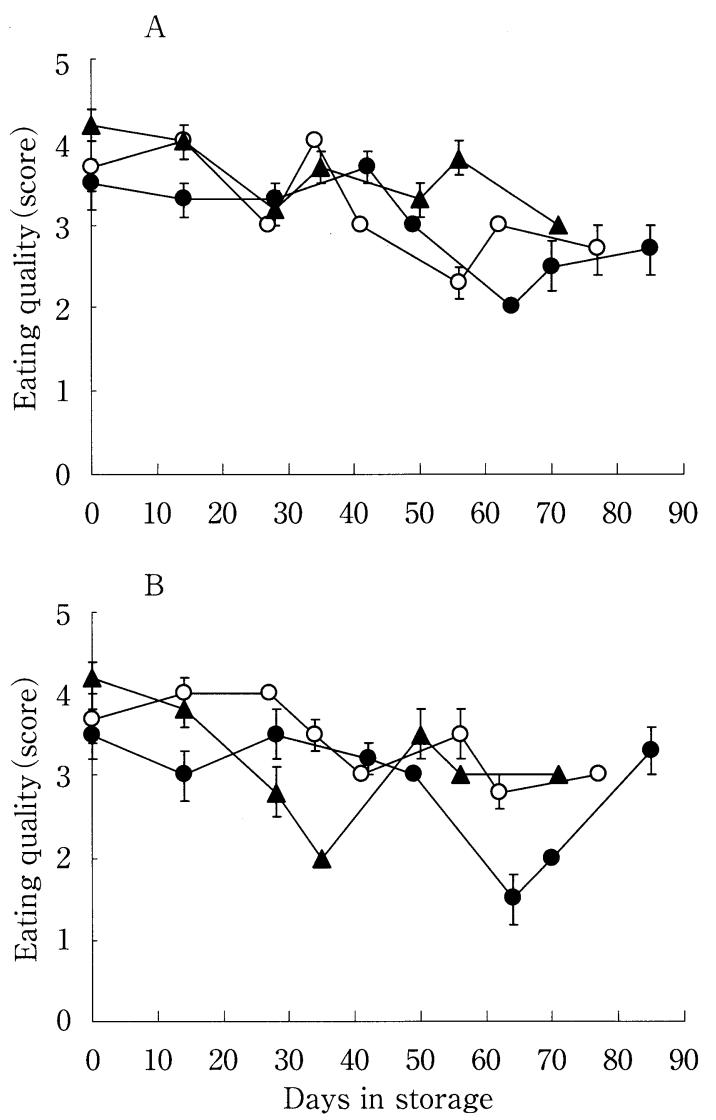

Fig. 5 Effects of harvest dates ( Nov. $2 ; \bigcirc$, Nov. $10 ; \boldsymbol{\Delta}$, Nov. 16) on changes in eating quality in Hiratanenashi persimmons packed in plastic film stored at $1{ }^{\circ} \mathrm{C}$ (A) and $5{ }^{\circ} \mathrm{C}(\mathrm{B})$

Scores of eating quality were 5 , very good $; 4, \operatorname{good} ; 3$, moderate ; 2 , edible but not good, and 1 , bad.

Bars represent SE $(n=6)$.

stored persimmons did not have serious problems in terms of eating quality at least for about 2 or 3 months at both storage temperatures. Moreover, the intensity of flesh darkening was almost the same among fruits harvested on the three different dates, resulting in a similar flesh texture.

\section{Discussion and Conclusions}

From the results presented in this report, the storability of persimmons packed individually in plastic film under cold storage was best in the fruit harvested about a week before full coloring of the fruit surface, in contrast to more mature fruits harvested at full coloring and over-ripe stages. We were able to store on-tree alcohol-treated persimmons for about 3 months at $1{ }^{\circ} \mathrm{C}$ while retaining fairly good taste.

ITAMURA ${ }^{4)}$ has already shown that the storability of astringent persimmons treated with ethanol vapor or carbon dioxide gas to remove astringency after 
harvest is better in fully colored fruits than in immature and over-ripe fruit in storage at $20^{\circ} \mathrm{C}$. The storability of fruit like apples, pears, and nonastringent persimmons in cold storage is generally better in those harvested a little before the fully ripe stage $^{1) \sim 31,5)}$. It is interesting that on-tree alcoholtreated persimmon fruit resemble non-astringent persimmons.

The flesh firmness of 'Hiratanenashi' fruits treated by carbon dioxide gas to remove astringency after harvest gradually decreased during storage ${ }^{7}$. In contrast, the flesh firmness of on-tree alcohol-treated fruits harvested at each stage of maturity did not decrease or changed very little during cold storage. This fact means that the quality of on-tree alcoholtreated persimmons may be more stable than that of post-harvest treated fruit.

Our results showed a tendency that the eating quality of on-tree alcohol-treated persimmons kept fairly well for about 3 months for the fruits stored at $1{ }^{\circ} \mathrm{C}$. However, fluctuations in the eating quality evaluations were sizable and also varied with storage period. Further examinations should be performed to analyze precisely the changes in eating quality of long-term-stored persimmons.

Acknowledgements We sincerely thank the staff of the Research Laboratory for Sources of Agricultural Products in Shonai District, Yamagata Prefecture, for providing fruit samples and technical assistance. We also profoundly thank JA Zenno Shonai and Dai-ichi Hoso Co. for their helpful support.

\section{References}

1) Westwood, M. N.: Temperate-zone pomology (W. H. Freeman and Company, San Francisco), pp. 261 282 (1978)

2) Kitagawa, H. : Persimmon culture and utilization (Yokendo, Tokyo), p. 157 (1970) (in Japanese)

3 ) TAIRA, S. : Fruit softening and storage in persimmon (Review), Agri. and Hort., 81, 802 810 (2006) (in Japanese)

4 ) Itamura, H. : Studies on fruit ripening and softening after removal of astringency in persimmon (Review), Food Preservation Science, 32, 81 88 (2006) (in Japanese)
5 ) Seymour, G. B., Taylor, J. E. and Tucker, G. A. (eds.) : Biochemistry of fruit ripening (Chapman and Hall, London), pp. 152 159 (1993)

6 ) TAIRA, S. and Isobe, S.: Effects of methods for removal of astringency and storage temperatures on storability in Hiratanenashi persimmon packed with plastic film, Food Preservation Science, 31, 261 265 (2005) (in Japanese with English abstract)

7 ) TAIRA, S. and ImAI, E.: Long-term storability of on-tree alcohol-treated Hiratanenashi persimmon packed in plastic film, Food Preservation Science, 33, in press (2007) (in Japanese with English abstract)

8 ) TAira, S. and TAKabayashi, N.: Effect of timing of on-tree treatment and duration of cold storage on astringency recurrence in 'Hiratanenashi' persimmon fruit, J. Japan. Soc. Food Sci. Technol., 53, 580 582 (2006) (in Japanese with English abstract)

\section{収穫時期の違いが}

\section{プラスチックフィルム包装したカキ ‘平核無” 樹上脱渋果の長期貯蔵性に及ぼす影響}

\author{
平 智* ·今井絵里子* ・五瓶正人* \\ * 山形大学農学部 \\ （９997-8555 山形県鶴岡市若葉町 1-23）
}

プラスチックフィルムで個別包装（個装）されたカキ ‘平核無' 樹上脱渋果の低温条件下における貯蔵性に及 ぼす果実の収穫時期の影響について検討した。

10月 3 日（満開後108日）に樹上でエ夕ノール処理を 行って脱渋した果実を，11月 2 日（果頂部のカラーチャ ート值約 5 ), 11月 10 日（果頂部のカラーチャート值約 6 で果面全面着色期）および11月16日（果頂部のカラー チャート值約 7 ）の 3 時期にそれぞれ収穫して個装した 後 $1{ }^{\circ} \mathrm{C}$ まは $5{ }^{\circ} \mathrm{C} て ゙$ 貯蔵した。

貯蔵実験の結果, いずれの収穫時期の果実でも $1{ }^{\circ} \mathrm{C}$ 貯 蔵果は $5{ }^{\circ} \mathrm{C}$ 貯蔵果よりも貯蔵性が優れた。また, 貯蔵温 度にかかわらず11月 2 日収穫果の貯蔵性が最も高かった。 果実の軟化率から判断した 11 月 2 日収穫果の $1{ }^{\circ} \mathrm{C}$ 貯蔵に おける貯蔵可能期間は約 3 か月であった。なお, 貯蔵温 度にかかわらずいずれの収穫時期の果実でも貯蔵中の果 皮色, 果肉硬度および果汁の可溶性固形物含量の変化は 小さかった。また，貯蔵果の食味は貯蔵期間が長くなる につれて若干低下する傾向が認められたが， $5{ }^{\circ} \mathrm{C}$ 貯蔵果 は $1{ }^{\circ} \mathrm{C}$ 貯蔵果より食味の変動が大きかった。11月 2 日収 穫の $1{ }^{\circ} \mathrm{C}$ 貯蔵果の食味は約 3 か月間ほぼ良好であった。

(平成 19 年 9 月 5 日受付, 平成 20 年 1 月 7 日受理) 